\title{
A PROPRIEDADE ANTE O NOVO PARADIGMA DO ESTADO CONSTITUCIONAL MODERNO: A SUSTENTABILIDADE ${ }^{1}$
}

PROPERTY IN THE LIGHT OF THE NEW PARADIGM OF THE MODERN CONSTITUTIONAL STATE: SUSTAINABILITY

LA PROPRIETÀ DI FRONTE AL NUOVO PARADIGMA DELLO STATO COSTITUZIONALE
MODERNO: LA SOSTENIBILITÀ

Emanuela Cristina Andrade Lacerda ${ }^{2}$

Alexandre Morais da Rosa ${ }^{3}$

Gabriel Real Ferrer ${ }^{4}$

1 Artigo desenvolvido com apoio da CAPES, por meio do Projeto de Doutorado Sanduíche, desenvolvido por ocasião do estágio para pesquisa na Universidade de Alicante, na Espanha.

2 Doutoranda do Curso de Programa de Pós-graduação em Ciência Jurídica da Universidade do Vale do Itajaí-SC. Lattes: CV: http://lattes.cnpq.br/5588795638008808.

3 Doutor em Direito (UFPR), com estágio de pós-doutoramento em Direito (Faculdade de Direito de Coimbra e UNISINOS). Mestre em Direito (UFSC). Professor Adjunto de Processo Penal e do CPGD (mestrado) da UFSC. Professor da UNIVALI. Juiz de Direito (SC). Pesquisa Judiciário, Processo e Decisão, com perspectiva transdisciplinar. Coordena o Grupo de Pesquisa Judiciário do Futuro (CNPq). Lattes: CV: http://lattes.cnpq.br/4049394828751754

4 Professor Doutor na Universidade de Alicante, Espanha. Departamento de "Estudios Jurídicos del Estado". Professor visitante do Programa de Pós-Gradução em Direito da UNIVALI. 
Resumo: A superação dos direitos individuais para se atender aos interesses sociais é latente nesta era de desenvolvimento global. Diante desse cenário, não há mais como vislumbrar a propriedade como um direito exclusivo, em que as faculdades inerentes ao proprietário são utilizadas de forma indiscriminada em prol de interesses pessoais tão somente. Antes disso, a sociedade global que emergiu após o exaurimento do Estado Moderno exige novos paradigmas, em especial a sustentabilidade, atendendo não somente a interesses locais, mas de toda a humanidade. O uso prejudicial da propriedade privada aqui pode gerar um problema irrecuperável do outro lado do planeta. Pensando assim, é que se vislumbra a necessidade de repensar os conceitos da Propriedade Privada em sua interação com o Meio Ambiente, em nome da sobrevivência sustentável e sadia no planeta, sem, contudo, violar os seus preceitos fundamentais. Esse, portanto o objeto do presente, pesquisar e verificar como o conceito de propriedade na atual sociedade pode ou deve evoluir para acompanhar as necessidades da sustentabilidade, entendida já como novo paradigma.

Palavras-chave: Propriedade Privada. Paradigma. Estado. Estado Constitucional Moderno. Sustentabilidade.

Abstract: Overcoming individual rights in order to cater for the interests of society is inherent in this era of global development. Given this scenario, property can no longer be seen as an exclusive right, in which the faculties inherent to the owner are used interchangeably solely in favor of personal interests. In view of this, the global society that has emerged after the exhaustion of the modern state requires new paradigms, in particular sustainability, serving not only local interests, but all of humanity. The harmful use of private property here, can generate an unrecoverable problem on the other side of the planet. It is with this thinking that one sees the need to rethink the concepts of private property in their interaction with the Environment, in favor of sustainable and healthy survival on the planet, without violating their fundamental precepts. The aim of this article, therefore, 
is to investigate and determine how the concept of ownership in today's society can or should evolve, to keep pace with the needs of sustainability, now understood as a new paradigm.

Keywords: Private Property. Paradigm. State. Modern Constitutional State. Sustainability.

Riassunto: Il superamento dei diritti individuali per soddisfare gli interessi sociali è qualcosa di latente in quest'epoca di sviluppo globale. Di fronte a questo scenario non si può intravedere la proprietà come un diritto esclusivo in cui le facoltà inerenti al proprietario vengano utilizzate in modo indiscriminato e a favore degli interessi personali, esclusivamente. Anzitutto, la società globale che emerse in seguito all'esaurimento dello Stato Moderno richiede nuovi paradigmi, e in particolare la sostenibilità, rispondendo non solo a interessi locali, ma all'intera umanità. L'uso indiscriminato della proprietà privata qui può creare dall'altra parte del pianeta un problema irreversibile. Ragionando in questo modo, si nota la necessità di ripensare i concetti di Proprietà Privata in termini di interazione con l'ambiente e volti alla sopravvivenza sana e sostenibile del pianeta, senza però violare precetti fondamentali. L'oggetto di questo lavoro è, quindi, quello di ricercare e verificare in che modo il concetto di proprietà nella società di oggi può o deve evolvere per stare al passo con le esigenze di sostenibilità, intesa ormai come nuovo paradigma.

Parole chiave: Proprietà Privata. Paradigma. Stato. Stato Costituzionale Moderno. Sostenibilità.

\section{INTRODUÇÃO}

propriedade, ao longo da história da humanidade, ocupou lugar
de grande destaque, seja quando guardava as características de
propriedade pública, exclusiva do Estado, seja quando já passa a 
ser admitida a propriedade privada, que segundo a tríade dos contratualistas Hobbes, Locke e Rousseau ${ }^{5}$, ocorreu somente com a formação do Estado.

Há muito, é sinônimo de status e poder, não sendo diferente nesta era de capitalismo marcadamente globalizado.

Superando-se os conceitos de um direito de propriedade caracteristicamente individual, ordem impressa pela Revolução Burguesa, cujas principais marcas eram as liberdades individuais e o Estado não intervencionista, tem-se a Propriedade poder-dever, que deve estar Inserida Socialmente.

Na Pós-Modernidade, além de se pensar nas questões de Inserção Social ${ }^{6}$, há que se ater a questões que superam o Estado Nacional e atingem todo o planeta, como é o caso dos problemas ambientais.

Considerando-se que a todos, falando-se inclusive de Estados Internacionais, é garantido um meio ambiente sadio, direito este amparado por diferentes Constituições, é que cumpre pensar e discutir acerca dos novos paradigmas da propriedade que atendam aos anseios de toda a humanidade, especialmente no que tange à mantença e à garantia da propriedade privada, sob o ponto de vista da sustentabilidade, o que necessariamente perpassa uma análise dessa garantia via constituição.

Assim sendo, a fim de atingir os objetivos comuns da propriedade privada e da sustentabilidade é que emerge a discussão sobre esse novo paradigma norteador das mudanças sociais e especialmente legislativas.

O objetivo é tecer uma análise dos conceitos clássicos da propriedade privada, do Estado Constitucional Moderno e sua evolução, para então analisar como a sustentabilidade vem se mostrando como o novo paradigma norteador da composição de novos conceitos de institutos fundamentais à Sociedade.

$5 \quad$ Em que pese se dar destaque para os citados autores, importante destacar que o contratualismo teve como representantes, além dos três referidos acima: J. Althusius (15571638), T. Hobbes (1588-1679), B. Spinoza (1632-1677), S. Puferndhorf (1632-1694), J. Locke (1632-1704), J. J. Rousseau (1712-1778), I. Kant (1724-1804), conforme Norberto Bobbio, in: BOBBIO, Norberto. MATTEUCCI, Nicola. PASQUINO, Gianfranco. Dicionário de Política. Trad. Carmem C. Varriale et al. coord. trad. João Ferreira. rev. geral João Ferreira e Luis Guerreiro pinto Cacais. Brasília: Universidade de Brasília. 12 ed. 2004, p. 272..

6 OliVEIRA, Álvaro Borges. Novos Estudos Jurídicos. In: A função $(\boldsymbol{f}(\boldsymbol{x}))$ do Direito das Coisas. V.11, n. 01. Jan-jun. 2006, p. 117-133. 


\section{O ESTADO CONSTITUCIONAL MODERNO}

A formação ou surgimento do Estado Constitucional Moderno pressupõe uma evolução do Estado a partir das suas formas mais antigas de organização. Todavia, dado o objeto do presente, parte-se de uma construção a partir do Estado Moderno.

Segundo Antonio Carlos Wolkmer, o Estado Moderno é oriundo de um processo histórico com início nos séculos XII/XIV, e se estendeu até o século XVIII, apresentando-se ora como Estado Absoluto (soberano, monárquico e secularizado) e ora como Estado Liberal (capitalista, constitucional e representativo) ${ }^{7}$.

O Estado Liberal, explica Norberto Bobbio, se consolidou com a Revolução Francesa de 1789, e se caracterizava por apresentar a mínima intervenção do Estado, havendo a supremacia constitucional e o império da lei, bem como houve a consagração do individualismo ${ }^{8}$ e da tolerância. Nesse mesmo sentido, Antonio Carlos Wolkmer ainda destaca que vigorava nessa forma de Estado o princípio da soberania popular e do governo representativo?.

Essa é concepção do Estado Liberal, cuja estrutura foi preparada a partir do Estado Absolutista, no qual a ordem feudal e a organização do poder ${ }^{10}$ na sua máxima 7 WOLKMER, Antonio Carlos. Elementos para uma crítica do Estado. Porto Alegre: Sergio Antonio Fabris Editor. 1990, p. 24-25.

8 Norberto Bobbio entende que a concepção individualista determina que o indivíduo venha em primeiro lugar, e como tal deve ser observado, ou seja, tem valor em si mesmo, e depois vem o Estado, que é feito para o indivíduo e não ao contrário (o indivíduo feito para o Estado). BOBBIO, Norberto. A era dos Direitos. Tradução Carlos Nelson Coutinho. Rio de Janeiro: Campus, 1992, p. 4.

9 WOLKMER, Antonio Carlos. Elementos para uma crítica do Estado. Porto Alegre: Sergio Antonio Fabris Editor, 1990, p. 24-25.

10 De acordo com a definição de Norberto Bobbio: "Em seu significado mais geral, a palavra Poder designa a capacidade ou a possibilidade de agir, de produzir efeitos. Tanto pode ser referida a indivíduos e a grupos humanos como a objetos ou a fenômenos naturais (como na expressão Poder calorífico, Poder de absorção). Se o entendermos em sentido especificamente social, ou seja, na sua relação com a vida do homem em sociedade, o Poder torna-se mais preciso, e seu espaço conceptual pode ir desde a capacidade geral de agir, até a capacidade do homem em determinar o comportamento do homem: Poder do homem sobre o homem. O homem é não só o sujeito, mas também o objeto do Poder social. É Poder social a capacidade que um pai tem para dar ordens a seus filhos ou a capacidade de um de um Governo de dar ordens aos cidadãos." BOBBIO, Norberto. MATTEUCCI, Nicola. PASQUINO, Gianfranco. Dicionário de Política. Trad. Carmem C. Varriale et. al. coord. trad. João Ferreira. rev. geral João Ferreira e Luis Guerreiro pinto Cacais. 12. ed. Brasília: Universidade de Brasília, 2004, p. 933-934. 
concentração predominavam, operando com fatores daí absorvidos, pois se aproveitavam das concepções absolutistas sob outra ótica, para possibilitar a sua governabilidade.

De acordo com José Luiz Bolzan de Moraes ${ }^{11}$, o Estado Liberal é oriundo da crítica ao Estado Monárquico Absolutista, dos séculos XVII e XVIII, no qual o rei era o soberano e exercia plenamente e sem qualquer limitação constitucional o poder. Esse poder do soberano, ou do rei, era de natureza divina ${ }^{12}$, e essa concentração de poder dava ao soberano direito sobre a vida, a liberdade e a propriedade de seus cidadãos, determinando ainda a vida econômica dos mesmos.

Para José Luiz Bolzan de Moraes, há, portanto, nessa sociedade a inexistência de concorrência de poderes, e a monarquia detém com exclusividade o mando sobre a vida das pessoas. E destaca que o liberalismo tem como pensadores e fomentadores: Rousseau ${ }^{13}$, Sieyès ${ }^{14}$, Montesquieu ${ }^{15}$, Diderot ${ }^{16}$, Voltaire ${ }^{17}$, Adam Smith $^{18}$, David Ricardo ${ }^{19}$, John Locke ${ }^{20}$, entre outros, sendo que todos consolidaram umbalanço críticoà sociedadeabsolutista-monarquistaqueculminou na Revolução Francesa, processo revolucionário de caráter político social que, de certa forma, coincidiu com o fenômeno de caráter científico-tecnológico que foi a Revolução Industrial; ambos os eventos históricos deram origem simultaneamente, por um lado, a um novo tipo de sociedade: a sociedade capitalista e, por outro, a um novo tipo de Estado: o Estado Liberal ${ }^{21}$.

11 BOLZAN DE MORAIS, José Luis. As crises do Estado e da Constituição e a transformação espacial dos direitos humanos. Porto Alegre: Livraria do Advogado, 2002, p. 24

12 DUGUIT, Léon. Fundamentos do Direito. Tradução Márcio Pugliesi. São Paulo: Ícone, 1996, p. 47-49.

13 ROUSSEAU, Jean-Jacques. Discurso sobre a origem e os fundamentos da desigualdade entre os homens. 1983.

14 SIEYÉS, Emmanuel Joseph. A constituinte burguesa (Qu' est-ce que le tiers état?). Tradução Norma de Azevedo. Rio de Janeiro: Liber Juris. 1986.

15 MONTESQUIEU, Charles de Secondat, Baron de. O espírito das leis. Tradução: Cristina Murachto. 2. ed. São Paulo: Martins Fontes, 1996.

16 DIDEROT, Denis. Obras I - Filosofia e Política. Tradução Jacó Guinsburg. 1. ed. São Paulo: Perspectiva, 2000.

17 VOLTAIRE, François Marie Arouet Le Jeune. Cartas Filosóficas. Tradução Renata Maria Pereira Cordeiro. São Paulo: Landy Editora, 2001.

18 SMITH, Adam. A Riqueza das Nações. Tradução Alexandre Amaral Rodrigues e Eunice Ostrensky. São Paulo: Martins Fontes, 2003.

19 RICARDO, DAVID. Princípios de economia política e tributação. Apresentação Paul Singer e Tradução Paulo Henrique Ribeiro Sandroni. São Paulo: Abril Cultural, 1982.

20 LOCKE, John. Segundo tratado sobre o governo civil e outros escritos. São Paulo: Abril Cultural, 1973 - Coleção Os Pensadores.

21 BOLZAN DE MORAIS, José Luis. As crises do Estado e da Constituição e a transformação espacial dos direitos humanos. Porto Alegre: Livraria do Advogado, 2002, p. 24. 
Em termos econômicos, verificou-se que a estrutura social do medievo se encontrava em decadência, e com isso cedia espaço para o surgimento e para o fortalecimento de uma nova sociedade na qual o comércio aparece como fonte fundamental de integração. $O$ desenvolvimento do comércio, e o patente crescimento da produção, do consumo e da acumulação de riquezas vão delineando o capitalismo ainda no seio da ordem feudal.

Nesse sentido, Karl Marx assinalou que "[...] a ordem econômica capitalista saiu das entranhas da ordem econômica feudal. A dissolução de uma produziu os elementos constitutivos da outra"22. A partir da Revolução Francesa, o patrimônio, segundo Norberto Bobbio, passou a valer mais que o indivíduo, a propriedade passa a ser o arrimo da nova sociedade, pois segundo o autor, "a esfera da propriedade foi sempre mais protegida do que a esfera da pessoa"23.

Corroborando desse entendimento, Vicente Barreto explica que o "Estado Liberal organizou-se, assim, de forma excludente; pela liberdade e igualdade, sim, mas prioritariamente dos proprietários"24.

E assim, na era moderna, a partir da extração de mão de obra das colônias, inicia-se o fenômeno denominado por Norberto Bobbio de acumulação primária de capital, a qual leva a um surpreendente desenvolvimento da indústria manufatureira e à concentração de capital. Paralelo a isso, surge o Capitalismo Moderno, formado por uma mão de obra carente de tudo que "com a Revolução Industrial passa da fase manufatureira à do maquinismo" 25 e, posteriormente, no fim do século XIX, leva a uma progressiva concentração societária do capital e ao aparecimento das sociedades acionarias gigantes, visando dominar a produção e o mercado mundiais "passa-se do capitalismo concorrencial ao capitalismo oligopolista e monopólico"26.

22 MARX, Karl. A origem do capital - a acumulação primitiva. Tradução Walter S. Maia. São Paulo: global. 1979, p. 15.

23 BOBBIO, Norberto. A Era dos Direitos. Tradução de Carlos Nelson Coutinho. Rio de Janeiro: Campus, 1992, p. 123.

24 BARRETO, Vicente. Ética, liberalismo e capitalismo. Revista Brasileira de Filosofia. São Paulo, v.2. fasc. 180, out/nov/dez 1995, p. 411.

25 BOBBIO, Norberto. MATTEUCCI, Nicola. PASQUINO, Gianfranco. Dicionário de Política. Trad. Carmem C. Varriale et. al. coord. trad. João Ferreira. rev. geral João Ferreira e Luis Guerreiro pinto Cacais. 12. ed. Brasília: Universidade de Brasília, 2004, p. 1033.

26 BOBBIO, Norberto. MATTEUCCI, Nicola. PASQUINO, Gianfranco. Dicionário de Política. 
Essa nova roupagem da economia e o tratamento à propriedade a partir da Época Moderna, surgida com a Revolução Francesa, intervêm na concepção individualista da sociedade, produto da Ideologia Liberal da Era Moderna, e faz imergir uma nova postura não intervencionista do Estado, o que se consolida a partir da Revolução Industrial e dos movimentos pela busca de direitos sociais, principalmente a partir da Constituição Mexicana em 1917 e a de Wiemar em 1919.

Segundo Cesar Luiz Pasold, a partir dessas duas Constituições houve uma ruptura na forma de Estado, culminando, a partir de então, com o surgimento e a confirmação do Estado Contemporâneo ${ }^{27}$. Para o autor, o Estado Contemporâneo é a sexta forma de Estado ${ }^{28}$, pois possui características peculiares que o diferenciam do superado Estado Moderno.

Paulo de Tarso Brandão ${ }^{29}$ sustenta, na mesma linha de pensamento de Cesar Luiz Pasold, que inúmeras circunstâncias foram determinantes para as transformações na estrutura material do Estado e que desencadearam a transformação do Estado Moderno no Estado Contemporâneo. Dentre esses elementos, destaca o autor, tem-se entre outros: "a organização do capitalismo com a modificação da livre concorrência de mercado; a racionalidade do poder legal, entendido como modo de transmissão de comando concreto; os movimentos sociais que eclodiram a partir da segunda metade do século XIX, ainda no seio do Estado Moderno; e, ainda, as novas concepções que impressionaram o pensamento político"30.

Já para Paulo Márcio Cruz, Estado Constitucional Moderno é tratado como "gênero, do qual Estado Liberal, Estado Social, Estado de Bem Estar, Estado Contemporâneo e todas as outras denominações dadas às variações de seu âmbito

Trad. Carmem C. Varriale et. al. coord. trad. João Ferreira. rev. geral João Ferreira e Luis Guerreiro pinto Cacais. 12. ed. Brasília: Universidade de Brasília. 2004, p. 1034.

27 PASOLD, Cesar Luiz. Função Social do Estado Contemporâneo. 3. ed. Florianópolis: OAB/SC Editora. Coedição Editora Diploma Legal. 2003, p. 57.

28 Cesar Luiz Pasold apresenta uma classificação dos tipos históricos fundamentais de Estados até então vivenciados, com base na Teoria de Jellinek, e assim os classifica: $1^{0}$ - os antigos Estados orientais; 2 o- o Estado Helênico; 3 o- o Estado Romano; 4 o- o Estado da Idade Média; 5 o- o Estado Moderno e 6 o- o Estado contemporâneo. PASOLD, Cesar Luiz. Função Social do Estado Contemporâneo. 3. ed. Florianópolis: OAB/SC Editora. Coedição Editora Diploma Legal. 2003, p. 29-34.

29 BRANDÃO, Paulo de Tarso. Ações Constitucionais: novos direitos e acesso à justiça. Florianópolis: Habitus, 2001, p. 41.

30 BRANDÃO, Paulo de Tarso. Ações Constitucionais: novos direitos e acesso à justiça. Florianópolis: Habitus, 2001, p. 53. 
de atuação são espécies" ${ }^{31}$, ou seja, há uma só matriz político-jurídica, com vários modelos que foram surgindo a partir de decisões ou necessidades ideológicas ${ }^{32}$.

Sob a ótica de Norberto Bobbio, essa distinção entre as formas de Estado é matéria por assaz controvertida na doutrina, em especial no que pertine "às relações entre a organização política e a sociedade ou às diversas finalidades que o poder político organizado persegue nas diversas épocas históricas e nas diversas sociedades". Diante disso, o autor entende que essas formas de Estado são "variadas e mutáveis que podem tornar incômoda, e talvez inútil, uma completa exposição delas"33.

As mudanças nas concepções estatais perpassam a questão terminológica, colimando com transformações na sociedade, na administração do poder público, bem como na forma de participação dos indivíduos nas decisões. Tais fatos são apontados como decorrentes das mudanças operadas no poder ${ }^{34}$, ou seja, na soberania estatal.

Segundo Paulo Márcio Cruz, um dos pilares teóricos do Estado Constitucional Moderno, é a transformação "da capacidade de coerção em Poder legítimo. Ou seja, na transformação do Poder de Fato em Poder de Direito", e que isso historicamente esteve vinculado ao conceito de Soberania ${ }^{35}$.

31 Sobre os conceitos dessas formas de Estado, ver: CRUZ, Paulo Márcio. Política, Poder, Ideologia e Estado Contemporâneo. 3. ed. Curitiba: Juruá. 2002, em especial p. 164-201.

32 CRUZ, Paulo Márcio. Ensaio sobre a necessidade de uma teoria para a superação democrática do Estado Constitucional Moderno. In: Novos Estudos Jurídicos. v.11. n.1. Jan-Jun. Itajaí: Universidade do Vale do Itajaí, 2006, p. 43.

33 BOBBIO, Norberto. Estado, governo, sociedade: para uma teoria geral da política. Tradução Marco Aurélio Nogueira. 9. ed. 1987. p. 113.

34 De acordo com a definição de Norberto Bobbio: "Em seu significado mais geral, a palavra Poder designa a capacidade ou a possibilidade de agir, de produzir efeitos. Tanto pode ser referida a indivíduos e a grupos humanos como a objetos ou a fenômenos naturais (como na expressão Poder calorífico, Poder de absorção). Se o entendermos em sentido especificamente social, ou seja, na sua relação com a vida do homem em sociedade, o Poder torna-se mais preciso, e seu espaço conceptual pode ir desde a capacidade geral de agir, até a capacidade do homem em determinar o comportamento do homem: Poder do homem sobre o homem. O homem é não só o sujeito, mas também o objeto do Poder social. É Poder social a capacidade que um pai tem para dar ordens a seus filhos ou a capacidade de um de um Governo de dar ordens aos cidadãos." BOBBIO, Norberto; MATTEUCCI, Nicola. PASQUINO, Gianfranco. Dicionário de Política. Trad. Carmem C. Varriale et al. Coord. trad. João Ferreira. rev. geral João Ferreira e Luis Guerreiro Pinto Cacais. 12 ed. Brasília: Universidade de Brasília, 2004, p. 933-934.

35 CRUZ, Paulo Márcio. Ensaio sobre a necessidade de uma teoria para a superação democrática do Estado Constitucional Moderno. In: Novos Estudos Jurídicos. v.11. n.1. Jan-Jun. Itajaí: Universidade do vale do Itajaí. 2006, p. 42. 
Coadunando desse pensamento, prescreve Cesar Luiz Pasold que o Estado Contemporâneo tem como função principal cumprir com eficácia sua Função Social, e para isso se vale, ou precisa valer-se, do Poder, sendo que este último tem sua origem na Nação ou no Povo ${ }^{36}$.

Esse Poder do Estado, de acordo com Norberto Bobbio, está atrelado ao conceito de soberania, e pode ser concebido de forma ampla ou restrita, sendo o conceito em sentido lato intimamente ligado ao Poder Político, e em sentido estrito, com significação moderna, aparece no final do Século XVI, junto com o Estado Absoluto, para caracterizar, de forma plena, o Poder estatal, sujeito único e exclusivo da política ${ }^{37}$.

Com o advento do Estado Constitucional Moderno e o consequente sobrepujar do Estado Absoluto, a Soberania foi transferida da pessoa do soberano para a Nação, que de acordo com Paulo Márcio Cruz, segue "a concepção racional e liberal defendida por pensadores como Emanuel Joseph Sieyès"38.

A teoria de Emanuel Joseph Sieyès estabelece a Soberania da Nação como instrumento de legitimação para a instituição do Estado Constitucional Moderno, ao afirmar que "em toda Nação livre - e toda Nação deve ser livre - só há uma forma de acabar com as diferenças que se produzem com respeito à Constituição. Não é aos notáveis que se deve recorrer, é à própria Nação"39.

Desse modo, Paulo Márcio Cruz defende que, desde seu início o Estado Constitucional Moderno teve em sua essência a manifestação da Soberania contrapondo qualquer interferência de poder externo. A consolidação do Princípio Democrático, portanto, pressupôs a reafirmação da Soberania em relação às decisões internas das comunidades, proibindo qualquer interferência externa ${ }^{40}$.

36 PASOLD, Cesar Luiz. Função Social do Estado Contemporâneo. Florianópolis: OAB/SC Editora. co-edição Editora Diploma Legal. 3. ed. 2003, p. 60.

37 BOBBIO, Norberto. MATTEUCCI, Nicola. PASQUINO, Gianfranco. Dicionário de Política. Trad. Carmem C. Varriale et al. coord. trad. João Ferreira. rev. geral João Ferreira e Luis Guerreiro pinto Cacais. Brasília: Universidade de Brasília. 12. ed. 2004, p. 1.179.

38 CRUZ, Paulo Márcio. Revista do Instituto de Pesquisas e Estudos: Divisão Jurídica. V. 41. Janeiro a Junho de 2007. Bauru: Edite. In: Soberania e superação do Estado Constitucional Moderno. 2007, p. 74.

39 SIEYĖS, Emanuel Joseph. A Constituinte Burguesa: (Qu'est-ce que le tiers état?). Traduçao Norma Azevedo. Rio de Janeiro: Liber Juris, 1986, p. 113-114.

40 CRUZ, Paulo Márcio. Revista do Instituto de Pesquisas e Estudos: Divisão Jurídica. V. 41. Janeiro a Junho de 2007. Bauru: Edite. In: Soberania e superação do Estado Constitu- 
Para José Eduardo Faria ${ }^{41}$, o moderno significado de soberania é sinônimo de um Poder de mando inquestionável, supremo, inalienável, independente e exclusivo de determinada sociedade política. Este poder é, finaliza o autor, "um poder sem igual ou concorrente, no âmbito de um território, capaz de estabelecer normas e comportamentos para todos os seus habitantes".

A partir da Segunda Guerra Mundial, em razão de tratados, convenções e acordos envolvendo diferentes Estados, fizeram emergir no seio destes certo deficit da sua Soberania, o que decorre da inevitável necessidade de ingressar no âmbito de uma sociedade internacional, vinculando cada Estado a normas e obrigações externas.

Essa integração do Estado em nível internacional levou a uma crise da Soberania e crise do próprio Estado, que segundo Norberto Bobbio é verificada tanto na teoria quanto na prática. Segundo o autor, "está desaparecendo a plenitude do poder estatal, caracterizada justamente pela Soberania; por isso, o Estado acabou quase se esvaziando e quase desapareceram seus limites"42.

Michael Hardt e Antonio Negri afirmam que o "declínio da soberania dos Estados-nação, entretanto, não quer dizer que a soberania como tal esteja em declínio", pois para os autores, as transformações contemporâneas concederam à Democracia uma nova forma, segundo eles, "composta de uma série de organismos nacionais e supranacionais, unidos por uma lógica ou regra única". Essa lógica ou regra única, ou nova forma global, é definida pelos autores como Império ${ }^{43}$, todavia alertam que esse Império não pode ser confundido com Imperialismo,

cional Moderno. 2007, p. 75.

41 FARIA, José Eduardo. O direito na economia globalizada. São Paulo: Malheiros, 1999, p. 21.

42 BOBBIO, Norberto. MATTEUCCI, Nicola. PASQUINO, Gianfranco. Dicionário de Política. Trad. Carmem C. Varriale et al. coord. trad. João Ferreira. rev. geral João Ferreira e Luis Guerreiro Pinto Cacais. 12. ed. Brasília: Universidade de Brasília. 2004, p. 1.187.

43 Sobre o conceito de Império destacam os autores: "O conceito de Império caracteriza-se fundamentalmente pela ausência de fronteiras: o poder exercido pelo Império postula um regime que efetivamente abrange a totalidade do espaço, ou que de fato governa todo o mundo "civilizado". Nenhuma fronteira territorial confina o seu reinado. [...] O objeto do seu governo é a vida social como um todo, e assim o Império se apresenta como forma paradigmática de biopoder. Finalmente, apesar de a prática do Império banhar-se continuamente em sangue, o conceito de Império é sempre dedicado à paz - uma paz perpétua e universal fora da História". HARDT Michael; NEGRI, Antonio. Império. Tradução de Berilo Vargas. 6. ed. Rio de Janeiro: Record, 2004, p. 14-15. 
pois se trata de "um aparelho de descentralização e desterritorialização do geral que incorpora gradualmente o mundo inteiro dentro de suas fronteiras abertas e em expansão"44.

A crise que perpassa o Estado Constitucional Moderno atual, portanto, decorre das inúmeras transformações que se operam na sociedade contemporânea, a exemplo da globalização, da transnacionalidade, dos avanços tecnológicos, entre outros. Essas transformações culminam com o surgimento de teorias que defendem a superação dessa forma de Estado, propondo inclusive novas concepções a exemplo do Estado Cooperativo ${ }^{45}$ de Peter Häberle ${ }^{46}$.

\section{A PROPRIEDADE E O ESTADO MODERNO}

O advento do Estado Moderno introduz na sociedade um poder de unificação do poder político fragmentado, e converge para o aperfeiçoamento de uma ordem jurídica baseada na lei e consubstanciada numa ótica individualista da sociedade. Garante certeza e estabilidade fundamentais à racionalidade econômica e eleva a propriedade ao grau de direito fundamental, pois passou a integrar os direitos garantidos constitucionalmente.

O Estado Constitucional, de acordo com Marcelo Cerqueira, surgiu a partir da Revolução Francesa, que se desenvolveu em duas tapas: uma revolução em favor do Estado Constitucional (1789-1791) e outra revolução (1792-1794) contra o Estado Constitucional ${ }^{47}$.

44 HARDT Michael; NEGRI, Antonio. Império. Tradução de Berilo Vargas. 6. ed. Rio de Janeiro: Record, 2004, p. 12.

45 O Estado Constitucional Cooperativo é o modelo teórico proposto por Peter Häberle para desenvolver seu pensamento em torno da proposta de uma teoria da Constituição como ciência da cultura. Como modelo teórico, o Estado Constitucional - que tem como fundamento a lógica da cooperação - busca aperfeiçoar os Estados de Direito existentes com elementos que possibilitem uma aproximação entre os povos por meio do elemento cultural. SILVA, Christine Oliveira Peter da; GONTIJO, André Pires. Análise Metodológica de Peter Häberle. Trabalho publicado nos Anais do XVII Congresso Nacional do CONPEDI, realizado em Brasília - DF nos dias 20, 21 e 22 de novembro de 2008. Disponível em: < http://www. conpedi.org.br/manaus/arquivos/anais/brasilia/02_816.pdf>

46 HABERLE, Peter. Per uma Dottrina dela Costituzione Come Scienza dela Cultura. Roma: CArocci, 2001.

47 CERQUEIRA, Marcelo. A Constituição na História: origem e reforma: da Revolução Inglesa de 1640 à crise do Leste Europeu. 2. ed. Rio de Janeiro: Revan. 2006. 
A Revolução Francesa ensaiaria, em poucos anos, diferentes sistemas políticos, como se realizasse experimentos dos modelos possíveis de democracia. Será o ponto de partida para o movimento de democratização que desde então impulsiona a história política dos povos. A Revolução Francesa fixou princípios políticos que, em seguida, se irradiaram para outros países e se mantêm permanentemente vivos: liberdade, igualdade e fraternidade ${ }^{48}$.

No que tange à propriedade, até então considerada como um direito natural, inviolável e sagrado, com a Declaração dos Direitos do Homem de 1789, passa a ser um direito absoluto, exclusivo, quase ilimitado ${ }^{49}$.

Assim considerada, possui estreita ligação com a visão atomística da sociedade, na qual o homem é senhor de si e de seus atos e ocupa especial lugar. Ao exercer seus atos, o indivíduo totalmente desvinculado dos outros indivíduos possui autonomia de agir, o que significa ser livre, e nesse aspecto a liberdade confundese com a propriedade, pois ser proprietário significa ser livre.

O nexo do instituto da propriedade não se restringia à liberdade, pois recebeu prestigio tal, que outros institutos como os contratos, o regime matrimonial, foram sistematizados no Código de Napoleão como um dos diversos modos de aquisição da propriedade ${ }^{50}$.

Assim a propriedade sob o pensamento do liberalismo ${ }^{51}$ transforma-se no mais importante dos direitos naturais, pressuposto de todos os outros. E dessa forma ingressou na codificação francesa, da qual influenciou as demais codificações liberais da época mantendo a mesma estrutura ${ }^{52}$.

48 CERQUEIRA, Marcelo. A Constituição na História: origem e reforma: da Revolução Inglesa de 1640 à crise do Leste Europeu. 2. ed. Rio de Janeiro: Revan. 2006, p.

49 GILLISEN, John. Introdução Histórica ao Direito. Tradução de Antonio Manuel Hespanha e Manuel Macaísta Malheiros. 4. ed. Lisboa: Fundação Calouste Gulbenkian. 2003, p. 646.

50 LOUREIRO, Francisco Eduardo. A propriedade como relação Jurídica Complexa. Rio de Janeiro: Renovar. 2003, p. 29.

51 LIBERALISMO, de acordo com Nicola Abbagnano é "[...] a doutrina que tomou para si a defesa e a realização da liberdade no campo político. Nasceu e afirmou-se na Idade Moderna e pode ser dividida em duas fases: $1^{\text {a }}$ do séc. XVIII, caracterizada pelo individualismo; $2^{\text {a }}$ do séc. XIX, caracterizada pelo estatismo". Entende ainda o autor que Stuart Mill, é um dos maiores representantes do Liberalismo, máxime em sua obra Sobre a Liberdade, a qual classifica como "uma das mais nobres e apaixonadas defesas da liberdade". ABBAGNANO, Nicola. Dicionário de Filosofia. São Paulo: Martins Fontes, 2000, p. 605.

52 CORTIANO JUNIOR, Erouths. O discurso jurídico da Propriedade e suas rupturas: uma análise do ensino do Direito de Propriedade. Rio de Janeiro: Renovar. 2002, p. 95/96. 
Nos séculos seguintes $\mathrm{XIX}$ e $\mathrm{XX}$, surgem extensões à propriedade, sobretudo no domínio dos bens incorpóreos, conforme observa John Gilissen, "o que antes não podia ser objeto de propriedade passou a sê-lo, de acordo com leis cada vez mais numerosas: as marcas de fábrica, as patentes de invenção, as obras artísticas e literárias, entre outras. Formou-se, assim, uma propriedade industrial, literária, artística e cientifica" ${ }^{13}$.

Além desse implemento nas características e nas formas de propriedade, as mudanças sociais passaram a influenciar sobremaneira os caracteres da propriedade, levando a evolução do absolutismo individual à noção de função social. Tal evolução adveio da contestação por toda a Europa acerca das reações provocadas pelo caráter individualista e absolutista até então impregnado à propriedade no Código Napoleônico de 1804.

No que tange aos dias atuais, transmuda-se mais uma vez a propriedade visando atender ao que se denomina atualmente de sustentabilidade, envolvendo ou atrelando novos paradigmas como meio ambiente, função social, inserção social, sustentabilidade, globalização $0^{54,55,56}$, entre outras.

53 GILLISEN, John. Introdução Histórica ao Direito. Tradução de Antonio Manuel Hespanha e Manuel Macaísta Malheiros. 4. ed. Lisboa: Fundação Calouste Gulbenkian. 2003, p. 647.

54 De acordo com Luiz Carlos Delorme Prado, "o conceito globalização começou a ser empregado desde meados da década de 1980, em substituição a conceitos como internacionalização e transnacionalização. [...] Somente ao fim da década de 1980 e, particularmente, na década de 1990 é que o termo globalização veio a ser empregado principalmente em dois sentidos: um positivo, descrevendo o processo de integração da economia mundial; e um normativo prescrevendo uma estratégia de desenvolvimento baseado na rápida integração com a economia mundial. [...]". Embora, destaque o autor que o conceito de globalização não é matéria pacífica na doutrina entende que, "como todo conceito imperfeitamente definido, Globalização significa coisas distintas para diferentes pessoas. Pode-se, no entanto perceber quatro linhas básicas de interpretação do fenômeno: (i)- globalização como uma época histórica; (ii)- globalização como um fenômeno sociológico de compressão do espaço e tempo; (iii) globalização como hegemonia dos valores liberais; (iv) globalização como fenômeno socioeconômico". PRADO, Luiz Carlos Delorme. Globalização: notas sobre um conceito controverso. Disponível em: www.ie.ufrj.br. Acesso em: 20/05/2007, às 16:24.

55 Jürgen Habermas, em sua obra "A inclusão do outro", sustenta que Anthony Guidens, foi um dos teóricos que pioneiramente tratou de conceituar e abordar sobre o fenômeno globalização, a definiu como "o adensamento, em todo o mundo, de relações que têm por consequência efeitos recíprocos desencadeados por acontecimentos tanto locais quanto muito distantes. HABERMAS, Jürgen. A inclusão do outro: estudos de teoria política. Tradução de George Sperber e Paulo Astor Soethe. São Paulo: Loyola, 2002, p. 138.

56 Francis Fukyama considera que a globalização representa a universalização dos valores de democracia liberal e ordem econômica baseada em princípios de economia de mercado, cujo exemplo ideal seria o modelo norte-americano. FUKUYAMA, Francis - The End of History and the Last Man. New York: Free Press,1992. 


\section{A FUNÇÃO SOCIOAMBIENTAL DA PROPRIEDADE E A SUSTENTABILIDADE}

O enfoque dado à propriedade e à sua função social insculpido no Artigo $5^{\circ} \mathrm{da}$ Constituição da República Federativa do Brasil de $1988^{57}$ refere-se à garantia e ao direito fundamental individual, porém, a propriedade não pode ser considerada um direito puramente individual, pois obedece também aos princípios da Ordem Econômica os quais têm por objetivo assegurar a existência digna, conforme os ditames da justiça social.

Para Konrad Hesse, ${ }^{58}$ "a base do asseguramento da existência e conformação de vida individual é, predominantemente, não mais a Propriedade privada no sentido tradicional do Direito Civil, senão o trabalho próprio e a participação nas prestações de assistência vital e assistência social estatal".

A propriedade privada atualmente deve estar ajustada, segundo Konrad Hesse, "a um sistema amplo de medidas de planificação, guia e coordenação, em medida crescente, também, de proteção do meio ambiente, no qual mal ainda entra em questão o sistema social e econômico atual, fundamentalmente, assente sobre a propriedade privada, a liberdade contratual e o autocomando", pois dessa forma atingirá os ditames constitucionais a que se propõem.

Francisco Garrido Peña ${ }^{59}$, no mesmo sentido defende que: "La propiedad privada es una institución que esta íntimamente vinculada con el concepto Del sujeto moderno y la representación de la libertad como ilimitada, característica también de la modernidad. Aquello que se tiene en propiedad se puede gozar y usar sin límites, sin más límites que la voluntad del propietario. Las libertades de los otros y los recursos naturales se vem amenazados por una institución que hace de cada propietario un soberano y un déspota. Es necesario pues limitar 57 Doravante apenas se utilizará CRFB/88.

58 HESSE, Konrad. Elementos de Direito Constitucional da República Federal da Alemanha. Tradução de Luís Afonso Heck. Porto Alegre: Sérgio Antonio Fabris Editor, 1998. p. 340.

59 PEÑA, Francisco Garrido. De como la ecologia política redefine conceptos centrales de la ontologia jurídica tradicional: liberdade y propiedad. In: VARELLA, Marcelo Dias \& BORGES, Roxana Cardoso Brasileiro (Orgs). O novo em direito ambiental. Belo Horizonte: Del Rey, 1998, p. 219. 
esta institución hasta la línea en que ponga en peligro las libertades de los otros o las condiciones ecológicas de reproducción de la vida".

A propriedade e a sua função social, ao serem incluídas na ordem econômica, exigem que a propriedade ligada às atividades econômicas atenda, além das necessidades particulares de seu proprietário, à sua função na sociedade e na defesa do meio ambiente equilibrado.

Verifica-se que a função social, ou melhor, Inserção Social ${ }^{60}, 61$, pode ser aplicada de várias formas. Se aplicada à propriedade privada, por exemplo, é a Inserção Social descrita no Artigo $5^{\circ}$ da CRFB/88; já se esta mesma propriedade estiver inclusa, também, como bem de produção, atenderá, além daquela Inserção Social, a Inserção Social do Artigo 170 da CRFB/88, cumulativamente, pois lá a propriedade é estática, aqui ela passa a ser dinâmica e consequentemente a Inserção que se dá a propriedade em relação à sociedade é diferente. Ainda, tanto numa como na outra forma de Inserção Social, não devem descuidar da função ambiental.

A CRFB/88, portanto, vinculou o cumprimento da função social às obrigações de defesa do meio ambiente, não sendo mais possível falar em propriedade privada absoluta e ilimitada. A propriedade sofre, sim, limitações e restrições, pois deve cumprir, além dos interesses do particular, também a função social e a função ambiental, pois conforme destaca Fernanda Cavedon ${ }^{62}$ :

A propriedade privada, absoluta e ilimitada, torna-se incompatível com a nova configuração dos direitos, que passam a tutelar Interesses Públicos, dentre os quais a preservação ambiental. Assim, o Direito de Propriedade adquire nova configuração, e passa a estar vinculado ao cumprimento de uma Função Social e Ambiental. É limitado no interesse da coletividade e a fim de adequar-se às novas demandas de ordem ambiental.

Em relação à efetivação da aliança entre os princípios da ordem econômica estabelecidos constitucionalmente e os relativos aos direitos e às garantias $\overline{60}$ OLIVEIRA, Álvaro Borges de. A função $(\mathrm{f}(\mathrm{x}))$ do Direito das Coisas. Novos Estudos Jurídicos, v. 11, p. 117-134, 2006.

61 OlIVEIRA, Álvaro Borges de. Uma Definição de Propriedade. Pensar (UNIFOR), v. 13, p. $10,2008$.

62 CAVEDON, Fernanda de Salles. Função social e ambiental da propriedade. Florianópolis: Visualbooks, 2003. p. 61. 
individuais concernentes à propriedade, deve-se procurar modelar as vantagens individuais e privadas do proprietário e os benefícios sociais e ambientais, referentes ao proveito coletivo. Essa é a propriedade que goza da tutela constitucional.

$\mathrm{Na}$ era das revoluções científica e industrial, o mundo era considerado uma enorme máquina, que trabalhava a todo vapor, utilizando de todos os recursos disponíveis em prol de seu crescimento, tendo como objetivo único o desenvolvimento tecnológico.

Paul E. Little diz que:

A Revolução Industrial intensifica as noções constituintes da sociedade moderna (separação sujeito e objeto, progresso, acúmulo de bens e riquezas etc.). A natureza passa a ser percebida a partir da racionalidade econômica, ou seja, torna-se recurso natural ou matéria-prima a ser apropriada no processo de transformação produtivo.

$[\ldots]$

Porém, a evidência dos problemas decorrentes desta maneira de conceber a natureza começa a encontrar um ambiente favorável ao seu afloramento [...]. O despertar de uma consciência das limitações dos recursos naturais, que antes eram vistos como infinitos, não ocorre por acaso. ${ }^{63}$

Ahumanidade, embuscadopodereconômico, aindatemumavisãoantropocêntrica e se esquece da preservação do meio ambiente para as próximas gerações.

A sustentabilidade emerge então como o novo paradigma ${ }^{64}$, capaz de equilibrar

63 LITTLE, Paul E. Políticas ambientais no Brasil: análises, instrumentos e experiências. p. 376.

64 Paradigma: A categoria "Paradigma", assim como tantas outras categorias, não possui um conceito operacional uníssono entre os doutrinadores, pois ao empreender essa tarefa, a ideologia e o âmbito social e cultural em que é tratada influenciam na construção da definição. Entretanto convém salientar que a primeira vez que o termo foi utilizado com especial rigor científico foi por meio de Thomas Khunn, na obra A Estrutura das Revoluções, em 1962. Nessa obra utiliza o termo "paradigma" para substituir o termo "verdade", em face da dificuldade em se definir o que pode ou não ser verdadeiro. Thomas Khun assinala que paradigma é aquilo, ou o entendimento sobre alguma coisa determinada, que os membros de uma mesma comunidade comungam e, enquanto tal, segue a matriz composta dos elementos: generalizações simbólicas; crenças em determinados modelos heurísticos e valores exemplares. Identifica a ciência como um discurso legitimado pela aceitação do grupo. KUHN, Thomas Samuel. A estrutura das revoluções científicas. Tradução de Beatriz Vianna Boeira e Nelson Boeira. 5. ed. São Paulo: Perspectiva, 2000, pp. 125 e 142 e ss. Ainda acerca da importância da conceituação do termo paradigma, destaca-se o pensa- 
esses poderes do proprietário e os deveres sociais e ambientais, sem se descurar com os objetivos de uma sociedade em constante mutação.

Pode-se conceituar-se como a busca do equilíbrio desse conjunto para que os recursos ambientais e o desenvolvimento socioeconômico garantam a proteção e a dignidade da vida, minimizando os riscos para as presentes e futuras gerações.

Para Enrique Leff, o princípio de sustentabilidade surge como a marca de um limite e o sinal que orienta o processo civilizatório da humanidade. A crise ambiental questiona a racionalidade e os paradigmas teóricos que impulsionaram o crescimento econômico e negaram a natureza. A sustentabilidade aparece como um critério normativo para a reconstrução da ordem econômica. ${ }^{65}$

A sustentabilidade tem como princípio proporcionar um ambiente saudável, conciliando o desenvolvimento econômico com a proteção e a preservação do meio ambiente. Com a vigência da CRFB/88, determinou-se que a ordem econômica observará a função social e ambiental, na qual demonstram os interesses coletivos sobre a propriedade, dentre eles o interesse de gozar de um ambiente saudável, como o desenvolvimento econômico individual que traga vantagens para a coletividade.

No entendimento de Cleide Calgaro, "a legislação brasileira, evolui muito ao tutelar a função social da propriedade, pois esta função está voltada principalmente

mento de Edgar Morin, que entende ser fundamental, pois no âmbito das ciências sociais, um paradigma, em todos os discursos proferidos, deve conter os conceitos fundamentais e as características mestras de inteligibilidade, bem como as relações lógicas existentes entre esses conceitos e categorias. Precisamente ao que ocorre com a evolução da "cientificização" da questão vital ambiental do planeta. MORIN, Edgar. 0 método 4: as idéias. 3. ed. Tradução de Juremir Machado da Silva. Porto Alegre: Sulina, 2002, p. 261. E por fim Paulo Marcio Cruz e Zenildo Bodnar, destacam a especial importância do termo para a ciência jurídica: "[...] no campo da Ciência Jurídica, com o Direito como seu objeto, por paradigma deve-se entender o critério de racionalidade epistemológica reflexiva que predomina, informa, orienta e direciona a resolução dos problemas, desafios, conflitos e o próprio funcionamento da sociedade. Trata-se de um referente a ser seguido e que ilumina a produção e aplicação do Direito. CRUZ, Paulo Marcio; BODNAR, Zenildo. Revista de Estudos Constitucionais, Hermenêutica e Teoria do Direito. In: O novo paradigma do direito na pós-modernidade. (RECHTD) 3(1): 75-83 janeiro-junho 2011 (c) 2011 by Unisinos - doi: 10.4013/rechtd.2011.31.08, Acesso em: 01/11/2013, às 11:56 (horário Espanha) 8:56 horário Brasil.

65 CALGARO, Cleide; HOFFMANN, Eliane Willrich. Função Social da Propriedade e Sustentabilidade. Boletim Jurídico, Uberaba/MG. Disponível em: <http://www.boletimjuridico.com. br/ doutrina/texto.asp?id=1394> Acesso em: 16/05/2012. 
para a questão socioambiental" ${ }^{66}$. Pois, assim, há uma maior cautela do Poder Público, fazendo com que sejam respeitadas as limitações e as restrições impostas sobre o direito de propriedade.

Conforme o Artigo 1.228, parágrafo $1^{\circ}$, do Código Civil de 2002, o direito de propriedade deve ser exercido sem prejudicar a flora, a fauna, as belezas naturais, o equilíbrio ecológico, o patrimônio histórico e artístico, e evitar a poluição do ar e das águas. Portanto, tem como objetivo o uso moderado dos recursos advindos de seu domínio da propriedade, atendendo às limitações e às restrições, garantindo que ela seja utilizada de maneira sustentável.

O direito de propriedade passa a ser objeto de limitações, tendo como objetivo a proteção legal do meio ambiente. O seu uso, gozo e fruição devem garantir a integridade do patrimônio ambiental, tendo, segundo Antônio Herman Benjamin, a propriedade privada que abandonar sua característica individualista e ingressar em uma nova fase, se submetendo a uma ordem pública ambiental ${ }^{67}$.

Há, portanto, a necessidade de integrar ao desenvolvimento da sociedade e do Estado outros critérios para se analisar a garantia de direitos individuais em prol dos interesses sociais mundiais. As fronteiras estatais no âmbito do direito ambiental são suprimidas e, como bem defende Peter Häberle, devem ser observadas e interpretadas sob o enfoque das diferentes culturas e das cronologias. Logo, o modelo do Estado Constitucional Cooperativo busca se colocar no lugar do Estado Constitucional Nacional, constituindo-se na resposta jurídico-constitucional à mudança no Direito Internacional: a passagem do "direito de coexistência" entre os Estados para a cooperação na comunidade de Estados, de modo que a sociedade aberta de intérpretes da Constituição torna-se uma sociedade aberta internacional.

As alterações que permeiam a sociedade e os Estados Nacionais são produtos das constantes mutações e necessidades que surgem com os avanços e a necessidade de transformações, especialmente no que tange a uma vida melhor

66 CALGARO, Cleide; HOFFMANN, Eliane Willrich. Função Social da Propriedade e Sustentabilidade. Boletim Jurídico, Uberaba/MG. Disponível em: <http://www.boletimjuridico. com.br/ doutrina/texto.asp?id=1394>.

67 CAVEDON, Fernanda de Salles. Função social e ambiental da propriedade. p. 123. 
e mais saudável para o planeta que igualmente possibilite a continuidade do desenvolvimento.

\section{A SUSTENTABILIDADE E O DESENVOLVIMENTO SUSTENTÁVEL COMO NOVOS ELEMENTOS DE EVOLUÇÃO}

A sustentabilidade e o desenvolvimento sustentável são institutos e/ou termos que não se confundem. Gabriel Real Ferrer ${ }^{68}$, ao se referir aos termos sustentabilidade e desenvolvimento sustentável, sustenta que:

Las palabras sirven para definir conceptos, pero a veces se usan para ocultarlos, para distraerlos sobre su autentico significado. Igualmente, su uso indiscriminado, espurio y banalizante, hace que se corra el riesgo de que unas y otras, palabras y conceptos, se diluyan en la nada, máxime cuando, como es el caso, se toman como una moda, como complemento a cualquier discurso políticamente correcto.

Assim sendo, tomando em conta o objetivo da presente investigação, cumpre destacar que o termo sustentabilidade será estudado a partir das suas dimensões e da fenomenologia de novo paradigma, posto que passou a integrar de forma incisiva e definitiva o ordenamento jurídico, vislumbrando um novo horizonte, conforme as necessidades e os postulados atuais, não se olvidando do antigo, porém mantendo o futuro como ponto de chegada.

O tema da sustentabilidade, ou como diz Edgar Morin ${ }^{69}$, a ideia de "suportabilidade", ingressou no universo jurídico somente modernamente, após a sociedade dar-se conta da degradação do meio ambiente ${ }^{70}$ em face do avanço

68 FERRER, Gabriel Real. Sostenibilidad, transnacionalidade y transformaciones del Derecho.

In: Direito ambiental, transnacionalidade e sustentabilidade [recurso eletrônico] Organizadores Maria Cláudia da Silva Antunes de Souza, Denise Schmitt Siqueira Garcia; Diego Richard Ronconi et al.. - 1. ed. Dados eletrônicos. - Itajaï: UNIVALI, 2013, p. 9

69 MORIN, Edgar. A Via para o futuro da humanidade. Tradução Edgard de Assis Carvalho; Maria Perasso Bosco. Rio de Janeiro: Bertrand. 2013. Titulo Original: La voie pour I'avenir de l'humanité, p. 32.

70 Meio Ambiente possui entre os doutrinadores da área, distintos conceitos, os quais englobam diferentes e muitas vezes comuns elementos, como o homem, a natureza (fauna e flora), o meio social, a cultura, entre outros, todavia, para José Rubens Moratto Leite, "qualquer que seja o conceito que se adotar, o meio ambiente engloba, sem dúvida, o homem e a natureza, com todos os seus elementos" e adverte que ""meio" e "ambiente" são sinônimos na acepção do termo e que a expressão "meio ambiente" é um pleonasmo, mas que se consagrou e foi 
tecnológico e do risco das gerações futuras quedarem-se sem meios para sobreviver (pelo menos sem recursos naturais) e sem ter como dar continuidade ao desenvolvimento econômico.

O fenômeno chamado por Luis Herrero de "câmbio social global" está mais do que premente nas sociedades atuais. Às mudanças no sistema ambiental se agregam ainda o aumento da população mundial, a globalização econômica, o desenvolvimento das ciências e da tecnologia. Tudo isso levou a um processo sem precedentes de degradação do planeta, que culmina na necessidade de transformação na "busca de un desarrollo humano sostenible que permita la coevolución del hombre y la naturaleza"71.

Todas as nações do mundo, como já mencionado, independentemente do regime social, do nível de conhecimento técnico-científico, a partir da evolução Industrial e, especialmente, em nome da busca pelo poder e pelo crescimento econômico, passaram a explorar de maneira inexorável os recursos disponíveis no meio ambiente.

O avanço da tecnologia e das pesquisas técnico-científicas permite processos de extração cada vez maiores dos recursos naturais, antes inacessíveis ou, até mesmo, inimagináveis pelo homem (explorar as profundezas dos oceanos, do espaço cósmico, etc.), passando a fazer parte do dia a dia dos Estados.

Na história da civilização, o "gen egoísta"72 do homem, o levou à exploração até à exaustão de grandes regiões, para então serem abandonadas e substituídas por outra mais produtiva. Os pequenos povoados, em face das grandes extensões de terra existentes, possibilitavam que qualquer degradação ou prejuízo fosse totalmente esquecido juntamente com a área que era substituída por outra fértil, quando das crescentes migrações verificadas na antiguidade e ao longo da Idade Média.

incorporada em várias legislações, e, apesar da redundância da composição, meio ambiente é comumente utilizado devido principalmente à fixação e arraigamento que se encontra na cultura nacional". LEITE, José Rubens Morato. Dano ambiental: do individual ao coletivo extrapatrimonial. São Paulo, Revista dos Tribunais, 2000.

71 HERRERO, Luis M. Jiménez. Cambio global, desarrollo sostenible y economia ecológica. In: HERRERO, Luis M. Jiménez; TAMARIT, Francisco J. Higón. Ecología y economia para un deserrollo sostenible. Patronat Sud-Nord. Solidaritat i Cultura - F.G.U.V. Publicacions de La Universitat de València: Valencia, ES. 2003, p. 17.

72 Essa expressão é tratada por Ramón Martín Mateo em sua obra Nuevos instrumentos para la tutela ambiental. Madri: Triviun, 1994, p. 147. 
Até o começo do século $\mathrm{XX}$, a amplitude das atividades desenvolvidas pelo homem era imperceptível, em face dos recursos naturais então existentes, e foram totalmente ignorados quaisquer possíveis malefícios.

Os primeiros danos irreparáveis deixados pelo homem podem ser verificados desde o feudalismo, assim como a exploração brutal, tanto da população escravagista, quanto da natureza. Em tempos bíblicos, remonta Grigori Jozin ${ }^{73}$, "el cedro del Líbano era considerado uno de los árboles más estimados y notables". O intenso corte dessas árvores, para uso nas diferentes aplicações que o homem almejava, levou ao completo desaparecimento dessa vegetação e, consequentemente, acarretou uma massiva alteração da natureza no local.

Outras nações não ficaram para trás, pois a ordem era o crescimento econômico, a expansão do seu território, o poder e, assim, Itália, Grécia e muitos outros países da Europa Ocidental perderam seus bosques. A colonização da América praticamente acabou com as florestas da Ilha de Cuba. Outros lugares, como Turquia, Grécia, Síria, Líbano, entre outros, sofreram com a omissão ante a derrubada de suas florestas e a destruição de grandes regiões de pastagem (estritamente necessária ao pastoreio naquela região) ${ }^{74}$.

Um grande número de agricultores que passou a povoar as famosas planícies nos Estados Unidos, famosas justamente pela exuberante vegetação, deram fim a tudo, acarretando, por conseguinte, sensíveis mudanças climáticas, a exemplo da grande seca de 1894 e as tempestades de areia de 1934, que praticamente varreram a superfície de grandes extensões de terras desses agricultores ${ }^{75}$. A Rússia, igualmente não ficou para trás, pois com o desenvolvimento industrial a todo vapor, ainda no século XVII, as fábricas de fundição de ferro iniciaram a extinção de bosques e o voraz aproveitamento das riquezas naturais. Aliados às empresas russas, outras companhias capitalistas deram cabo a praticamente todas as florestas e recursos naturais que puderam.

73 JOZIN, Grigori. Business contra la naturaleza. Traducão para o espanhol de Alexandr Noga. Editorial de la Agencia de Prensa Nóvosti: Moscou. 1984, p. 05.

74 JOZIN, Grigori. Business contra la naturaleza. Traducão para o espanhol de Alexandr Noga. Editorial de la Agencia de Prensa Nóvosti: Moscou. 1984, p. 05.

75 JOZIN, Grigori. Business contra la naturaleza. Traducão para o espanhol de Alexandr Noga. Editorial de la Agencia de Prensa Nóvosti: Moscou. 1984, p. 06. 
Esse descuido se verifica também nas péssimas condições de trabalho, o que é registrado por Engels sobre as condições dos trabalhadores de Londres, Liverpool, Manchester e outras cidades, nas quais a falta de sistemas de esgoto e de ventilação; a contaminação do ar em razão da evaporação dos resíduos e a falta de fornecimento de água são causas de grandes contaminações e mortandade entre os trabalhadores da época ${ }^{76}$.

A sociedade, na busca insaciável de poder e capital, olvidou-se tanto da natureza quanto da salubridade do ambiente à disposição da população, o que acarretou, obviamente, uma grande ameaça às gerações vindouras.

Com o passar dos tempos e após muitos Estados começarem e dar-se conta que o arsenal natural, fonte de bens materiais, de saúde e bem-estar do homem, disponíveis pela natureza, estava a ponto de extinguir-se, iniciaram discussões, manifestações, reuniões e toda sorte de programas para não só entender o que está acontecendo com o planeta, mas também para buscar possíveis soluções ${ }^{77}$.

Apósaverificaçãodeinúmerosdesastresnaturais, aliadoàsincipientesinvestigações científicas, e tendo ainda a luta dos ecologistas e a pressão da opinião pública, não só no âmbito nacional, senão em âmbito internacional, se obtêm os primeiros resultados, tais como a produção de informes, a celebração de conferências sobre o meio ambiente e os inúmeros encontros entre nações para tratar do meio ambiente em seus diferentes aspectos, abordando diferentes temas e preocupações.

76 ENGELS, Friedrich. A situação da classe trabalhadora na Inglaterra. Tradução $B$. A. Schumann; Edição José Paulo Netto. São Paulo: Boitempo, 2008. Titulo Original: Die Lage der Arbeitenden Klasse in England, sendo esta a primeira obra do autor, escrita a partir de suas próprias observações.

77 De acordo com Gabriel Real Ferrer: "Aunque que el interés por las expediciones cientificas decayó a finales del XVII durante el XIX prosiguieron las exploraciones, así [arte de las realizadas por Alexander von HUMBOLD se desarrollaran en ese siglo, del mismo mdo que las de LIVINGSTONE, quien bautiza a las cataratas Victoria en 1855. Australia no sejó de ser colônia penitenciaria hasta 1852 y AMUNDSEN no llegó al Polo Sur hasta 1911. Las exploraciones cientificas y sistemáticas a largo plazo de la Antartida comenzaron cone I Aõ Geofisico Internacional (1 de julio de 1957 al 31 de diciembre de 1958) en el que doce países establecieron más de sessenta estaciones cientificas en la Antartida recorrendo buena parte de su território y completando, de algun modo, em mapa de la Tierra (aunque debe recordarse que, en 1891, el congresso Internacional de Geografia propuso cartografar el mundo enterro a una escala 1:1.000.000, tarea que se desarrollo durante muchos años y nunca concluyó). El impulso innato o cultural del hombre por descobrir nuevos horizontes, nuevas tierras prometidas, se canaliza entonces hacia el espacio exterior y hacia el mundo submarino, epro pronto se compreende su limitación." FERRER, Gabriel Real. La construción del Derecho Ambiental.

Revista Arazandi de Derecho Ambiental. Pamplona, Espanha. N. 1, 2002, p. 4 
Em que pese esse movimento que surge entre os anos sessenta e setenta ser muito diferente das primeiras tentativas intentadas no sentido de proteção do meio ambiente, posto que surge em meio a protestos políticos e crise ecológica, redundou numa difusão das ideias e inferiu uma resposta tanto da sociedade quanto das instituições políticas, o que acarretou a normatização meio ambiental em muitos países.

Gabriel Real Ferrer, embora afirme que a fixação de uma data sobre o nascimento do direito ambiental é inútil senão para uma via didática, admite que se isso for para fixar a emergencialidade do direito ambiental, entende que poderia se fixar como a "acta de nascimiento de Derecho Ambiental [...] diciembre de 1969, cuando en Estados Unidos se adopta la National Environmental Policy Act", a qual passa a exigir avaliação de impacto ambiental para determinadas atuações, tendo sido a "primera institución jurídica propiamente ambiental"78.

Ainda que exista essa divergência acerca do início do movimento entre os teóricos da área, pode-se verificar que a luta por transformações em prol do meio ambiente saudável tem sido a bandeira do movimento ecologista desde o século XIX. O incipiente processo de industrialização, o pedido, por diferentes setores, por melhoras ao meio ambiente e o surgimento da ecologia como ciência marcam o compasso de uma nova forma de entender o mundo.

Após surgirem as primeiras formulações ecologistas no sentido de lutar para conservar o meio ambiente, tem início a criação de organizações filantrópicas ainda no século XIX; todavia, somente na segunda metade do século XX é que tomam o protagonismo esperado ${ }^{79}$.

Emergem, também, as primeiras tratativas teóricas e dogmáticas que contribuem para a evolução jurídica do tema "proteção ambiental", dentre elas podem se destacar teóricos em diferentes países, a exemplo de Ramón Marin

78 FERRER, Gabriel Real. La construción del Derecho Ambiental. Revista Arazandi de Derecho Ambiental. Pamplona, Espanha. N. 1, 2002, p. 6.

79 Keneth E. Boulding apresentou, pelo menos uma década antes dos informes de Clube de Roma, importantes trabalhos acerca do crescimento degenerado da humanidade e da economia em detrimento dos recursos disponíveis e, é sua a frase: "quem crê que o crescimento pode durar para sempre em um mundo finito, ou é um louco ou um economista". FERRER, Gabriel Real. La construción del Derecho Ambiental. Revista Arazandi de Derecho Ambiental. Pamplona, Espanha. N. 1, 2002, p. 5 nota 08. 
Mateo na Espanha; Cano e Pigretti na Argentina; Rebhinder e Bothe na Alemanha; Michel Prieur e Kiss na França; dentre outros ${ }^{80}$.

Gabriel Real Ferrer observa que, para um correta compreensão do Direito Ambiental, necessário empreender diferentes enfoques, em especial três dos quais, "su progresso cronológico" para os quais se refere como "'olas" y su progresión técnico-jurídica, tienen que ver con su manifestación más externa o superficial y, el terceiro, con su evolución conceptual y su incardinación en el sistema social actual, aspectos mucho más profundos y enjudiosos"81.

No tocante às "olas", identifica, na primeira, o caráter demográfico, impregnado como enfoque dos estudos e das discussões, o que motiva a construção e a proliferação de legislações no sentido de estabelecer limites ao crescimento de muitos países. Nessa época, já se vislumbra, por parte de alguns juristas, a importante evolução que se aproxima e destaca o limite de crescimento como novo paradigma dessa fase ${ }^{82}$.

Na segunda "ola", em que pese os avanços serem verificados somente no plano teórico e na prática deixar a desejar, o crescimento de organizações não governamentais, ou agentes sociais, comprometido com a proteção ambiental, aumentou substancialmente e desenvolveram-se legislações a partir da Conferência realizada em 1992. Note-se que, apesar desse crescimento da proteção por meio das legislações, Gabriel Real Ferrer destaca que "uno de los resultados visibles de la Cumbre es que todos los países se aprestam a dotarse de abundante y moderna legislación ambiental, dando lugar a una oleada de normas a la que alguna vez he denominado la "generación de la fotocopia" pues se reproducen unas a otras sin consideración alguna a la realidade social, económica, jurídica y ambiental sobre la que se proyetan". Essas legislações, em muitos casos, apresentam altos índices de exigência, o que se louva, entretanto, em aspectos práticos e efetivos, pouco se verificou ${ }^{83}$.

80 FERRER, Gabriel Real. In: Classes de Derecho e Sostenibilidad, ministradas no Curso de Doutorado na Universidade de Alicante. Outubro de 2013.

81 FERRER, Gabriel Real. La construción del Derecho Ambiental. Revista Arazandi de Derecho Ambiental. Pamplona, Espanha. N. 1, 2002, p. 6.

82 FERRER, Gabriel Real. La construción del Derecho Ambiental. Revista Arazandi de Derecho Ambiental. Pamplona, Espanha. N. 1, 2002, p. 6-7.

83 FERRER, Gabriel Real. La construción del Derecho Ambiental. Revista Arazandi de Derecho Ambiental. Pamplona, Espanha. N. 1, 2002, p. 9. Destaque mantido conforme o original. 
Nessa fase, o paradigma do limite do crescimento amplia para o de um modelo de desenvolvimento, aliado ao combate da pobreza, pois se identifica que o imprescindível para garantir um meio ambiente saudável a todos, necessário é que os países pobres sejam atendidos e, assim, emerge a solidariedade.

Os problemas são identificados, as legislações já preveem medidas para preservação, entretanto, não se dispõe de um meio de coação ou de uma autoridade que obrigue as nações a cumprir com os compromissos assumidos ${ }^{84}$.

Por fim, na terceira onda, destaca o caráter político que emerge necessário em termos de proteção ambiental. Mostra-se necessário que, para atingir os níveis de proteção e solidariedade esperados, que exista uma governabilidade em nível internacional ${ }^{85}$.

Assim evoluiu o Direito Ambiental e, conforme os problemas foram sendo percebidos ou constatados por meio das diferentes áreas, seja jurídica, sociológica, econômica, tecnológica ou científica, foram surgindo movimentos e emergindo soluções, ainda que apenas teóricas, a fim de alcançar uma solução de mantença da vida no planeta aliada à mantença dos recursos naturais disponíveis.

Há ainda, para os economistas, um terceiro caráter fundamental, para o qual a sustentabilidade do ecossistema está condicionada a uma complexa integração de fatores biológicos, físicos e socioeconômicos, que constituem a base de todos os sistemas produtivos e que envolvem ainda os sistemas de gestão ${ }^{86}$.

Progressivamente, os conceitos tradicionais, para assegurar a exploração dos recursos às taxas compatíveis com o crescimento da biomassa, de acordo com Luis Jimenez Herrero, vão se incorporando "a los cambios de la economía, la sociología y la política hasta adquirir una dimensión múltiple e integral". Para atingir o nível esperado sobre a estruturação conceitual, a essas mudanças agregam-se ainda as noções ecológicas de resiliência e capacidade de carga, em conjunto com as 84 FERRER, Gabriel Real. La construción del Derecho Ambiental. Revista Arazandi de Derecho Ambiental. Pamplona, Espanha. N. 1, 2002, p. 9.

85 FERRER, Gabriel Real. La construción del Derecho Ambiental. Revista Arazandi de Derecho Ambiental. Pamplona, Espanha. N. 1, 2002, p. 10-11.

86 HERRERO, Luis M. Jiménez. Cambio global, desarrollo sostenible y economia ecológica. In: HERRERO, Luis M. Jiménez; TAMARIT, Francisco J. Higón. Ecología y economia para un deserrollo sostenible. Patronat Sud-Nord. Solidaritat i Cultura - F.G.U.V. Publicacions de La Universitat de València: Valencia, ES. 2003, p. 43-48. 
noções econômicas de capital natural e a noção social de equidade, as quais se entrelaçam para definir "más que un estilo de desarrollo, incluso una forma de vida sostenible, arropadas por nuevas consideraciones éticas" ${ }^{\prime \prime 7}$.

Efetivamente, os conceitos iniciais de sustentabilidade ligados às atividades agrárias, ou melhor, ao ecossistema agrário, apresentam um caráter diferenciado, em que cumpre, num primeiro momento, suprir as necessidades mutantes de uma população em pleno desenvolvimento e crescimento até sua plena estabilização, ou seja, a preocupação inicial era manter as necessidades quantitativas e qualitativas e, posteriormente, manter ou melhorar a qualidade do meio ambiente.

De uma maneira geral, as ciências, em sua grande maioria, passaram a incluir a sustentabilidade na pauta de suas pesquisas e discussões, ainda que, por vezes criticada, a exemplo dos ecologistas em relação aos economistas, vez que entendem que a sustentabilidade para o economista sobrevive apenas para garantir o desenvolvimento econômico, fato é que a mantença do ecossistema deverá ser a premissa de todos, seja por que objetivo for.

Deixando de lado a divergência entre ecologistas e economistas, o que não se discute é a necessidade de rever as formas de desenvolvimento e crescimento, ou seja, ainda que sob enfoques distintos, o resultado almejado é comum nos discursos, qual seja, a necessidade de mudança, ou seja, a metamorfose sugerida por Edgar Morin ${ }^{88}$ está latente no seio de todas as sociedades, e esta será a verdadeira origem.

O termo sustentabilidade emerge, portanto, e ganha cada vez mais espaço nos discursos do desenvolvimento e/ou do desenvolvimento econômico, pelos quais a sociedade precisa crescer atentando para a mantença de forma perdurável dos recursos naturais ambientais sobre os quais descansa a exploração econômica ${ }^{89}$.

87 HERRERO, Luis M. Jiménez. Desarrollo sostenible: transición hacia la coevolución global. Ediciones Pirámide: Madrid. 2000, p. 103. Destaque em itálico conforme o original.

88 MORIN, Edgar. A Via para o futuro da humanidade. Tradução Edgard de Assis Carvalho; Maria Perasso Bosco. Rio de Janeiro: Bertrand. 2013. Titulo Original: La voie pour I'avenir de I'humanité.

89 HERRERO, Luis M. Jiménez. Cambio global, desarrollo sostenible y economia ecológica. In: HERRERO, Luis M. Jiménez; TAMARIT, Francisco J. Higón. Ecología y economia para un deserrollo sostenible. Patronat Sud-Nord. Solidaritat i Cultura - F.G.U.V. Publicacions de La Universitat de València: Valencia, ES. 2003, p. 43. 
Nesse sentido, seja sob a ótica dos ecologistas ou dos economistas, a necessidade de mantença de um crescimento equilibrado e sustentável é fundamental e não são poucos que passam a tratar da sustentabilidade como sinônimo de desenvolvimento sustentável.

De qualquer forma, longe de propor uma conceituação estanque e definitiva, Gabriel Real Ferrer entende a sustentabilidade como a capacidade de uma sociedade permanecer indefinidamente no tempo, desde que obedeça aos atuais padrões culturais e civilizacionais para respeitar a capacidade dos meios naturais no qual opera e, podendo alcançar níveis de justiça social e econômicos que a dignidade da pessoa humana exige ${ }^{90}$.

De acordo ainda com Gabriel Real Ferrer, o termo sustentabilidade diz respeito às atividades necessárias para se garantir uma vida do ecossistema saudável e não pode ser confundido com desenvolvimento sustentável.

Somente por meio de ações que propugnassem a preservação ambiental, é que se poderia ter o equilíbrio tão almejado pela sustentabilidade. As ações deveriam iniciar pelo meio ambiente, pilar principal da sustentabilidade e, assim, posteriormente, prosseguir ao social e ao econômico, igualmente necessários para garantir uma sobrevivência sustentável da raça humana no planeta. Atenta para este fato e frisa que são conceitos totalmente diferentes, e que precisam ser cuidadosamente empregados, sob pena de olvidar do verdadeiro sentido, dos verdadeiros objetivos da sustentabilidade ${ }^{91}$.

Ramón Martin Mateo, de forma otimista, defendia que "[...] Aunque estamos en estos momentos ayunos tanto de soluciones definitivas jurídicas como tecnológicas globalmente satisfactorias, podemos constatar, con una cierta satisfacción, que al menos existe una naciente conciencia sobre la necesidad de arbitrar medidasjurídicas que hagan imperativas las conclusiones técnicamente conseguidas, para encauzar

90 FERRER, Gabriel Real. Sostenibilidad, transnacionalidad y transformaciones del Derecho. In: Revista de Derecho Ambiental: Doctrina, Jurisprudencia, Legislacion y practica. Director: Néstor A. Cafferatta. Buenos Aires: Abeledo Perrot. Octubre/deciembre 2012, p. 65-82

91 FERRER, Gabriel Real. Direito ambiental, transnacionalidade e sustentabilidade. Organizadores Maria Cláudia da Silva Antunes de Souza; Denise Schmitt Siqueira Garcia; Diego Richard Ronconi et al. 1. ed. Dados eletrônicos. - Itajaí: UNIVALI, 2013, p. 11 
científicamente por cauces tranquilizadores el curso de la humanidad"92.

Ainda há muito para se evoluir, entretanto, se os objetivos econômicos estiverem aliados aos objetivos e às necessidades de preservação dos recursos naturais para continuidade da exploração e do crescimento, será possível um conluio social em prol do equilíbrio almejado por todos.

\section{CONSIDERAÇÕES FINAIS}

O desenvolvimento da sociedade civil e do Estado constituiu-se a base da superação de importantes ciclos e conquistas. As necessidades e as carências, à medida que surgem, obrigam o homem a buscar alternativas e respostas para a solução de seus conflitos, respostas estas que nem sempre são facilmente encontradas, mas que devem ser buscadas nas experiências passadas.

As novas necessidades e as exigências surgidas no âmbito da Sociedade, dentre as quais as de ordem ambiental, requerem uma reorientação do Direito num sentido social e ambiental, é por esse motivo que o Direito de Propriedade apresenta-se como um direito renovado, que passa a agregar em suas concepções a sustentabilidade, a fim de adequar-se às demandas sociais e ambientais da coletividade. Essa nova roupagem da Propriedade vincula a eficácia da Função Socioambiental e do desenvolvimento econômico, convertendo-a em um instituto híbrido, no qual os interesses das diferentes esferas - público, privado e social mundial - recebem proteção.

A preocupação com a preservação do meio ambiente e a continuidade do crescimento econômico são temas que estão interligados e fazem parte da construção da tutela ambiental e da proteção da propriedade.

A sustentabilidade começa a apresentar seus contornos, uma vez que passa a integrar os discursos e as preocupações de todas as nações. Ao assumir e substituir o paradigma do crescimento, que agora passa a constituir os objetivos

92 MARTIN MATEO, Ramón. La Sostenibilidad para el desarrollo. La cumpre de Johannesburgo. In: MANGAS MARTÍN, Victor-Javier (Coordinador). Educación Ambiental y Sostenibilidad. Alicante. Universidad de Alicante. 2003, p. 19. 
das nações, o adjetivo sustentável incorpora o objetivo de crescimento e passase a tratar, então, de desenvolvimento sustentável.

As diretrizes que passaram a integrar os planos de desenvolvimento e a proteção da propriedade igualmente passaram a incluir a sustentabilidade como meta a ser alcançada em prol de uma sociedade em constante crescimento, garantindo-se um meio ambiente equilibrado sem prejuízo da garantia dos direitos individuais.

Com os "Oito Objetivos do Milênio" apresentados no ano 2000, nasce a ideia para fazer frente aos principais objetivos comuns das nações com a finalidade de se alcançar o tão almejado equilíbrio para a continuidade do crescimento, especificamente são eles: "1: acabar com a fome e a miséria; 2: educação básica para todos; 3: igualdade entre os sexos e valorização da mulher; 4: reduzir a mortalidade infantil; 5: melhorar a saúde da gestante; 6: combater a Aids, a malária e outras doenças; 7: qualidade de vida e respeito ao meio ambiente; 8: todo mundo trabalhando pelo desenvolvimento". ${ }^{93}$

Há que se ter o cuidado, entretanto, para não confundir os termos - sustentabilidade e desenvolvimento sustentável - que por vezes são convenientemente confundidos, mas, como defende Gabriel Real Ferrer, trata-se de uma dicotomia na qual a sustentabilidade opera negativamente, pois seria um limite ao desenvolvimento sustentável se não observados os reais e necessários objetivos da preservação da vida humana.

A noção de sustentabilidade, portanto, corresponde à consciência de conservar um determinado sistema produtivo, ou, mais recentemente, o patrimônio natural para as gerações vindouras sem provocar o esgotamento das fontes naturais ou ainda sem provocar efeitos irreversíveis, o que garante o desenvolvimento sustentável.

Atualmente os conceitos de desenvolvimento econômico ou de preservação do meio ambiente coexistem e passam a ser inseparáveis, mesmo porque a sociedade e o capitalismo são processos irreversíveis e que necessitam apenas

93 Disponível em: <http://www.objetivosdomilenio.org.br/> Acesso em: 06 de novembro de 2013, às 12:50 (horário da Espanha) e 9:50 (horário do Brasil). 
de elementos que conciliem os interesses sociais com os individuais de forma harmônica e progressista.

De conseguinte, a reflexão proposta no presente trabalho tem por objetivo evidenciar a necessidade de repensar na produção do direito, especialmente no que tange à propriedade privada no sentido de assegurar um desenvolvimento sustentável, que garanta às presentes e futuras gerações a existência de um planeta seguro, cujo bem-estar depende do equilíbrio do ecossistema que o acolhe, não se descurando da garantia necessária à propriedade para garantir o pleno desenvolvimento econômico na atual sociedade capitalista.

\section{REFERÊNCIAS}

ABBAGNANO, Nicola. Dicionário de Filosofia. São Paulo: Martins Fontes, 2000.

BARRETO, Vicente. Ética, liberalismo e capitalismo. Revista Brasileira de Filosofia. São Paulo, v.2. fasc. 180, out/nov/dez 1995.

BOBBIO, Norberto. A Era dos Direitos. Tradução Carlos Nelson Coutinho. Rio de Janeiro: Campus, 1992.

. Estado, governo, sociedade: para uma teoria geral da política. Tradução Marco Aurélio Nogueira. 9. ed. 1987.

MATTEUCCI, Nicola; PASQUINO, Gianfranco. Dicionário de Política. Trad. Carmem C. Varriale et. al. coord. trad. João Ferreira. rev. geral João Ferreira e Luis Guerreiro pinto Cacais. Brasília: Universidade de Brasília. 12 ed. 2004.

BOLZAN DE MORAIS, José Luis. As crises do Estado e da Constituição e a transformação espacial dos direitos humanos. Porto Alegre: Livraria do Advogado, 2002.

BRANDÃO, Paulo de Tarso. Ações Constitucionais: novos direitos e acesso à justiça. Florianópolis: Habitus, 2001.

CALGARO, Cleide; HOFFMANN, Eliane Willrich. Função Social da Propriedade e Sustentabilidade. Boletim Jurídico, Uberaba/MG. Disponível em: <http://www.boletimjuridico. com.br/ doutrina/texto.asp?id=1394>

CAVEDON, Fernanda de Salles. Função social e ambiental da propriedade. Florianópolis: Visualbooks, 2003. 
CERQUEIRA, Marcelo. A Constituição na História: origem e reforma: da Revolução Inglesa de 1640 à crise do Leste Europeu. 2. ed. Rio de Janeiro: Revan, 2006.

CORTIANO JUNIOR, Erouths. O discurso jurídico da Propriedade e suas rupturas: uma análise do ensino do Direito de Propriedade. Rio de Janeiro: Renovar. 2002.

CRUZ, Paulo Márcio. Ensaio sobre a necessidade de uma teoria para a superação democrática do Estado Constitucional Moderno. In: Novos Estudos Jurídicos. v.11. n.1. Jan-Jun. Itajaí: Universidade do Vale do Itajaí. 2006.

Política, Poder, Ideologia e Estado Contemporâneo. 3. ed. Curitiba: Juruá. 2002.

Soberania e superação do Estado Constitucional Moderno. In: Revista do Instituto de Pesquisas e Estudos: Divisão Jurídica. V. 41. Janeiro a Junho de 2007. Bauru: Edite. 2007.

. Paulo Marcio; BODNAR, Zenildo. O novo paradigma do direito na pós-modernidade. In: Revista de Estudos Constitucionais, Hermenêutica e Teoria do Direito. (RECHTD) 3(1): 75-83 janeiro-junho 2011 (C) 2011 by Unisinos - doi: 10.4013/rechtd.2011.31.08, Acesso em 01/11/2013, às 11:56 (horário Espanha) 8:56 horário Brasil.

DIDEROT, Denis. Obras I - Filosofia e Política. Tradução Jacó Guinsburg. São Paulo: Perspectiva. 1. ed. 2000.

DUGUIT, Leon. Fundamentos do Direito. Tradução Márcio Pugliesi. São Paulo: ícone. 1996.

Lãs Transformaciones Del Derecho - Publico y Privado. Tradução Adolfo G. Posada e Ramón jaés. Buenos Aires: Editorial Heliasta, s/d.

ENGELS, Friedrich. Princípios Básicos do Comunismo, outubro/novembro de 1847. Tradução Álvaro Pena et alii. Lisboa: Avante. 1978.

FARIA, José Eduardo. O direito na economia globalizada. São Paulo: Malheiros, 1999.

FERRER, Gabriel Real. Direito ambiental, transnacionalidade e sustentabilidade. Organizadores Maria Cláudia da Silva Antunes de Souza; Denise Schmitt Siqueira Garcia; Diego Richard Ronconi. [et al.]. 1. ed. - Dados eletrônicos. - Itajaí : UNIVALI, 2013.

. Gabriel Real. La construción del Derecho Ambiental. Revista Arazandi de Derecho Ambiental. Pamplona, Espanha. N. 1, 2002.

Gabriel Real. Sostenibilidad, transnacionalidade y transformaciones del Derecho. In: Direito ambiental, transnacionalidade e sustentabilidade [recurso eletrônico]. 
Organizadores Maria Cláudia da Silva Antunes de Souza, Denise Schmitt Siqueira Garcia ; Diego Richard Ronconi... [et al.]. - 1. ed. Dados eletrônicos. - Itajaí: UNIVALI, 2013.

Gabriel Real. Sostenibilidad, transnacionalidad y transformaciones del Derecho. In: Revista de Derecho Ambiental: Doctrina, Jurisprudencia, Legislacion y practica. Director: Néstor A. Cafferatta. Buenos Aires: Abeledo Perrot. Octubre/deciembre 2012.

FUKUYAMA, Francis - The End of History and the Last Man, New York, Free Press, 1992.

GILLISEN, John. Introdução Histórica ao Direito. Tradução de Antonio Manuel Hespanha e Manuel Macaísta Malheiros. 4. ed. Lisboa: Fundação Calouste Gulbenkian, 2003.

HABERLE, Peter. Per uma Dottrina dela Costituzione Come Scienza dela Cultura. Roma: CArocci, 2001.

HABERMAS, Jürgen. A inclusão do outro: estudos de teoria política. Tradução de George Sperber e Paulo Astor Soethe. São Paulo: Loyola, 2002.

HARDT Michael; NEGRI, Antonio. Império. Tradução de Berilo Vargas. 6. ed. Rio de Janeiro: Record, 2004.

HERRERO, Luis M. Jiménez. Cambio global, desarrollo sostenible y economia ecológica. In: HERRERO, Luis M. Jiménez; TAMARIT, Francisco J. Higón. Ecología y economia para un deserrollo sostenible. Patronat Sud-Nord. Solidaritat i Cultura - F.G.U.V. Publicacions de La Universitat de València: Valencia, ES. 2003.

. Luis M. Jiménez. Desarrollo sostenible: transición hacia la coevolución global. Ediciones Pirámide: Madrid. 2000, p. 103. Destaque em itálico conforme o original.

HESSE, Konrad. Elementos de Direito Constitucional da República Federal da Alemanha. Tradução de Luís Afonso Heck. Porto Alegre: Sérgio Antonio Fabris Editor, 1998.

JOZIN, Grigori. Business contra la naturaleza. Traducão para o espanhol de Alexandr Noga. Editorial de la Agencia de Prensa Nóvosti: Moscou. 1984.

KUHN, Thomas Samuel. A estrutura das revoluções científicas. Tradução de Beatriz Vianna Boeira e Nelson Boeira. 5. ed. São Paulo: Perspectiva, 2000.

LEITE, José Rubens Morato. Dano ambiental: do individual ao coletivo extrapatrimonial. São Paulo, Revista dos Tribunais, 2000.

LITTLE, Paul E. Políticas ambientais no Brasil: análises, instrumentos e experiências. 
LOCKE, John. Segundo tratado sobre o governo civil e outros escritos. São Paulo: Abril Cultural, 1973. Coleção Os Pensadores.

LOUREIRO, Francisco Eduardo. A propriedade como relação Jurídica Complexa. Rio de Janeiro: Renovar. 2003.

MARTIN MATEO, Ramón. La Sostenibilidad para el desarrollo. La cumpre de Johannesburgo. In: MANGAS MARTÍN, Victor-Javier (Coordinador). Educación Ambiental y Sostenibilidad. Alicante: Universidad de Alicante. 2003.

Nuevos instrumentos para la tutela ambiental. Madri: Triviun, 1994.

MARX, Karl. A origem do capital - a acumulação primitiva. Tradução Walter S. Maia. São Paulo: Global, 1979.

. ENGELS, Friedrich. Manifesto do Partido Comunista (1848). Tradução: Sueli Tomazini Barros Cassal. Porto Alegre: LPM. 2006.

MONTESQUIEU, Charles de Secondat, Baron de. O espírito das leis. Tradução: Cristina Murachto. 2. ed. São Paulo: Martins Fontes, 1996.

MORIN, Edgar. A Via para o futuro da humanidade. Tradução Edgard de Assis Carvalho; Maria Perasso Bosco. Rio de Janeiro: Bertrand. 2013. Titulo Original: La voie pour l'avenir de I’humanité.

- Edgar. O método 4: as idéias. 3. ed. Tradução de Juremir Machado da Silva. Porto Alegre: Sulina, 2002.

MOREIRA DA COSTA, Cássia Celina Paulo. A Constitucionalização do Direito de Propriedade Privada. Rio de Janeiro: América Jurídica. 2003.

OLIVEIRA, Álvaro Borges de. A função $(f(x))$ do Direito das Coisas. Novos Estudos Jurídicos, v. 11.2006.

. Uma Definição de Propriedade. Pensar (UNIFOR), v. 13, p. 10, 2008.

. Novos Estudos Jurídicos. In: A função (f(x)) do Direito das Coisas. V.11, n. 01. Jan-jun. 2006.

PASOLD, Cesar Luiz. Função Social do Estado Contemporâneo. 3. ed. Florianópolis: OAB/SC Editora. Coedição Editora Diploma Legal, 2003.

PEÑA, Francisco Garrido. De como la ecologia política redefine conceptos centrales de la ontologia jurídica tradicional: liberdade y propriedad. In VARELLA, Marcelo Dias \& BORGES, Roxana Cardoso 
Brasileiro (Orgs). O novo em direito ambiental. Belo Horizonte: Del Rey, 1998.

PRADO, Luiz Carlos Delorme. Globalização: notas sobre um conceito controverso. Disponível em: www.ie.ufrj.br.

PROUDHON, Pierre Joseph. O que é a propriedade? São Paulo: Martins Fontes. 1988.

RICARDO, DAVID. Princípios de economia política e tributação. Apresentação Paul Singer e Tradução Paulo Henrique Ribeiro Sandroni. São Paulo: Abril Cultural. 1982.

ROUSSEAU, Jean-Jacques. Discurso sobre a origem e os fundamentos da desigualdade entre os homens. 1983.

SIEYÈS, Emanuel Joseph. A Constituinte Burguesa: (Qu'est-ce que le tiers état?). Traduçao Norma Azevedo. Rio de Janeiro: Liber Juris, 1986.

SILVA, Christine Oliveira Peter da; GONTIJO, André Pires. Análise Metológica de Peter Häberle. Trabalho publicado nos Anais do XVII CONGRESSO Nacional do CONPEDI, realizado em Brasília - DF nos dias 20, 21 e 22 de novembro de 2008. Disponível em < http://www.conpedi. org.br/manaus/arquivos/anais/brasilia/02_816.pdf>

SMITH, Adam. A Riqueza das Nações. Tradução Alexandre Amaral Rodrigues e Eunice Ostrensky. São Paulo: Martins Fontes. 2003.

VARELLA, Marcelo Dias \& BORGES, Roxana Cardoso Brasileiro (Orgs). 0 novo em direito ambiental. Belo Horizonte: Del Rey, 1998.

VIANA, Marco Aurélio S. Tutela da Propriedade Imóvel. São Paulo: Saraiva. 1982.

VOLTAIRE, François Marie Arouet Le Jeune. Cartas Filosóficas. Tradução Renata Maria Pereira Cordeiro. São Paulo: Landy Editora. 2001.

WOLKMER, Antonio Carlos. Elementos para uma crítica do Estado. Porto Alegre: Sergio Antonio Fabris Editor. 1990. 